\title{
Matrix Approach to Assessing Competitiveness of Regions: From Methodology to Practice
}

\author{
Marat R. Safiullin ${ }^{1,2}$, Azat R. Safiullin ${ }^{1}$, Leonid A. Elshin ${ }^{1,2} \&$ Maria I. Prygunova $^{2}$ \\ ${ }^{1}$ Kazan Federal University, Russian Federation \\ ${ }^{2}$ Center of Advanced Economic Research Academy of Sciences of the Republic of Tatarstan, Kazan, \\ Ostrovskogo str. 23, Kazan, Russian Federation \\ Correspondence: Marat R. Safiullin, Kremlevskaya str. 18, Kazan, 420008, Russian Federation. E-mail: \\ c.p@tatar.ru
}

Received: June 3, 2014 Accepted: July 21, 2014 Online Published: September 28, 2014

doi:10.5539/ass.v10n20p47 URL: http://dx.doi.org/10.5539/ass.v10n20p47

\begin{abstract}
The article considers methodological aspects of grouping regions of a federal district by the degree of their competitiveness in the sectoral markets with account of determination of the probability of transition of a certain economic activity from one group of competitiveness to another. At that, an effort is for the first time taken to substantiate the matrix approach to determination of the competitiveness of sectoral markets, which allows taking into account all possible combinations of the market competitive profile of a region, which combines all possible combinations of localization and concentration of manufacture. The authors carry out experimental computations regarding assessment of competitiveness of the industrial profile of the Republic of Tatarstan in the Volga Federal District, and based on that develop probabilistic forecasts of transition of certain economic activities of the Republic of Tatarstan from one competitiveness group to another.
\end{abstract}

Keywords: competitiveness, regional development, industrial profile, localization, concentration, differentiation

\section{Introduction}

The key to increasing the potential of economic growth and stability of the regional economics is the formation of institutional, infrastructural and other conditions that would encourage activation of economic activity and target reinforcement of competitive positions of the profile types of economic activity as well as the developing and potentially possible ones. It is found particularly important in the circumstances of aggravating competition in all types and kinds of nation-wide and regional markets as a result of implementation of integration mechanisms of Russia into the global trade-coordinating structures and in the global markets as a result of aggravating political and economic situation.

In the circumstances of the expected stagnation of economic dynamics (against the background of slowdown of the growth rate of the nation-wide and global economies), one of the key objectives of the regional policy becomes formation and reinforcement of competitive advantages of certain economic activities targeting creation of more stable and balanced economy, which would be less dependent on various uncertainties (Safiullin, Elshin, \& Shakirova, 2012). Besides, it is necessary to develop regional types of economic activities and their market share growth in the regional and nation-wide markets in order to ensure regional competitiveness as a whole, and increase of diversification and differentiation of the gross regional product, which would allow reducing dependence on the revenue gained from extraction of minerals.

It requires comprehensive and complete analysis of the competitive advantages of certain types of economic activity on the level of individual regions and the whole district, and revelation of the types of markets, in which they carry out their activity in order to determine obstacles and prospects of their development.

\section{Methodology}

The research was carried out based on methodological approaches developed during scientific and research work performed in 2012 and dedicated to analysis of structural gaps in competitiveness of production facilities of the petrochemical cluster of the Republic of Tatarstan (Gafurov, Safiullin, \& Safiullin, 2012) based on information sources of the Federal State Statistics Service, the Local Body of the Federal State Statistics Service in the Republic of Tatarstan, as well as analytical information of the State Budget-funded Institution "The Center of 
Prospective Economic Research of the Academy of Sciences of the Republic of Tatarstan".

Competitiveness of enterprises engaged in a certain type of economic activity must be determined based on two-level analysis. On the first level, assessment of the competitive market profile is carried out following the results of analysis of the main parameters describing the level of specialization and concentration of market manufacturers of commodities and services (the ratios of localization and concentration). On the second level, assessment of individual indicators revealing the existing peculiarities of the production efficiency (labor and capital productivity) is carried out. Thus, the comprehensive assessment of competitiveness of market manufacturers includes determination of external and internal parameters (Figure 1).

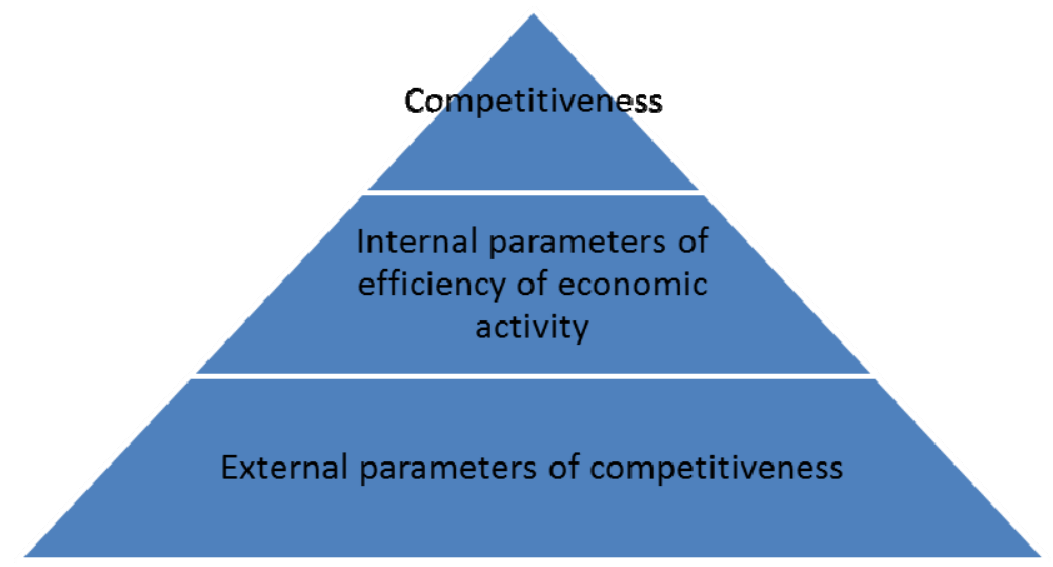

Figure 1. Comprehensive assessment of the competitiveness of types of economic activity

At that, according to the authors' opinion, the primary objective at diagnostics of competitiveness of market productions must be assessment of external parameters describing the trends and prospects of the market conjuncture profile (the degree of specialization, localization, concentration, and differentiation of the market-integrated production facilities) (Safiullin, Elshin, \& Shakirova, 2013). These factors particularly determine the prospects of regional localization and development of production facilities with account of the emerging trends in the market.

The internal parameters of market-integrated production facilities are equally important at assessment of competitiveness. Their analysis allows revealing the strong and weak sides of the production efficiency compared to the market average values and standards. This in turn considerably facilitates understanding of the development prospects of certain external economic activity with account of the trends in the regional, district-wide and nation-wide markets (Safiullin et al., 2013). At the same time, within this study, the considered stage of the analysis is not represented because of content-related and volume limits.

The basic fact is that the assessment of competitiveness of the industrial types of the economic activity of the Republic of Tatarstan is based on the principles and classification of the market-integrated profile (Table 1). The developed table containing data describing the market profile parameters was built in the form of a matrix, which allows taking into account all possible combinations of the market competitive profile of the region, which combines all possible combinations of the ratio of localization and concentration of production.

Since 1982, the Department of Justice of the USA has been using the Herfindahl-Hirschman Index (HHI)-the index of market concentration-as the main characteristic of the sectoral markets structure. This index is determined as a total of squared shares of volumes of shipped products of each entity (territory) in the sectoral market.

$$
H H I=\sum_{n=1}^{N} S_{n}^{2}
$$

where $S_{n}$ is the share of the $\mathrm{n}^{\text {th }}$ territory's products in the total of shipped products throughout the country.

If the value of the index is within the $0 \ldots 1,000$ interval, the market is deemed weakly concentrated; between 1,000 and 1,800-medium concentrated; and if it exceeds 1,800-the market is highly concentrated.

During the analysis of the sectoral markets structure on the mesolevel, the index of concentration is to be 
supplemented with the index of localization (IL).

$$
I L=\frac{D_{j k n}}{D_{j k}}
$$

where $D_{j k n}$ is the share of shipped products of $\mathbf{j}^{\text {th }}$ type of economic activity either in the total amount of shipped products in the $\mathrm{k}^{\text {th }}$ section of OKVED (the All-Russian Classifier of Types of Economic Activity) or in the whole industry product in the $\mathrm{n}^{\text {th }}$ territory, $D_{j k}$ is the share of the shipped products of $\mathrm{j}^{\text {th }}$ type of economic activity either in the total amount of shipped products in the $\mathrm{k}^{\text {th }}$ section of OKVED or in the whole country(district)-wide industry product.

If the estimated values of the index are more than 1, this type of economic activity is relevant to the territory and has competitive advantages or potential attractiveness for further development (if it is equal to 1, the type of economic activity only meets local demand and is oriented mainly to the internal market). If the index of localization has a value below 1, the territory is not specialized on this type of economic activity, and the internal demand is met with commodities imported from other territories.

\section{Results}

The results of distribution of the types of economic activities in accordance with the qualification attributes represented in Table 1 are provided below in the bubble chart (Figure 2) as exemplified by the types of economic activities related to the chemical and related to it sectors of industry of the Republic of Tatarstan (the X-axis is the index of localization (IL), the Y-axis is the market concentration index ( $\underline{\mathbf{H H I}})$ ).

Table 1. Classification and characteristics of the regional competitive profile

\begin{tabular}{|c|c|c|c|c|c|c|c|}
\hline $\begin{array}{l}\text { Market } \\
\text { type } \\
\text { group } \\
\text { number }\end{array}$ & $\begin{array}{l}\text { Market profile } \\
\text { parameters }\end{array}$ & $\begin{array}{l}\text { Competiti } \\
\text { on degree } \\
\text { in the } \\
\text { market }\end{array}$ & Market type & $\begin{array}{l}\text { Degree of } \\
\text { the region's } \\
\text { competitive } \\
\text { ness }\end{array}$ & $\begin{array}{l}\text { Market } \\
\text { characteristic }\end{array}$ & $\begin{array}{l}\text { Probability of } \\
\text { losing the market } \\
\text { share due to } \\
\text { worsening of } \\
\text { competitive } \\
\text { advantages }\end{array}$ & $\begin{array}{l}\text { Degree of } \\
\text { substitution } \\
\text { with } \\
\text { imports in } \\
\text { the internal } \\
\text { market }\end{array}$ \\
\hline I. & $\begin{array}{l}\mathrm{HHI}<1,000, \\
0<\mathrm{IL}<1\end{array}$ & High & $\begin{array}{l}\text { Free } \\
\text { competition } \\
\text { market }\end{array}$ & Low & $\begin{array}{l}\text { Multiple } \\
\text { manufacturers, } \\
\text { low degree of } \\
\text { the region } \\
\text { specialization. }\end{array}$ & High & High \\
\hline II. & $\begin{array}{l}\mathrm{HHI}<1,000, \\
\mathrm{IL}>1\end{array}$ & Increased & $\begin{array}{l}\text { Monopolistic } \\
\text { competition } \\
\text { market }\end{array}$ & $\begin{array}{l}\text { Medium } \\
\text { high }\end{array}$ & $\begin{array}{l}\text { Multiple } \\
\text { manufacturers, } \\
\text { high degree of } \\
\text { the region } \\
\text { specialization. }\end{array}$ & Moderate & $\begin{array}{l}\text { Medium } \\
\text { low }\end{array}$ \\
\hline III. & $\begin{array}{l}1,000<\mathrm{HHI}<1 \\
800,0<\mathrm{IL}<1\end{array}$ & $\begin{array}{l}\text { Above } \\
\text { average }\end{array}$ & $\begin{array}{l}\text { Oligopolistic } \\
\text { competition } \\
\text { market }\end{array}$ & $\begin{array}{l}\text { Below } \\
\text { average }\end{array}$ & $\begin{array}{l}\text { Concentration } \\
\text { degree: } \\
\text { medium/low } \\
\text { degree of the } \\
\text { region } \\
\text { specialization }\end{array}$ & High & High \\
\hline IV. & $\begin{array}{l}1,000<\mathrm{HHI}<1 \\
800, \mathrm{IL}>1\end{array}$ & medium & $\begin{array}{l}\text { Oligopolistic } \\
\text { competition } \\
\text { market with } \\
\text { tending to } \\
\text { change for a } \\
\text { pure } \\
\text { monopoly } \\
\text { market }\end{array}$ & Medium & $\begin{array}{l}\text { Concentration } \\
\text { degree: } \\
\text { medium/high } \\
\text { degree of the } \\
\text { region } \\
\text { specialization }\end{array}$ & Low & Low \\
\hline
\end{tabular}




\begin{tabular}{|c|c|c|c|c|c|c|c|}
\hline $\begin{array}{l}\text { Market } \\
\text { type } \\
\text { group } \\
\text { number }\end{array}$ & $\begin{array}{l}\text { Market profile } \\
\text { parameters }\end{array}$ & $\begin{array}{l}\text { Competiti } \\
\text { on degree } \\
\text { in the } \\
\text { market }\end{array}$ & Market type & $\begin{array}{l}\text { Degree of } \\
\text { the region's } \\
\text { competitive } \\
\text { ness }\end{array}$ & $\begin{array}{l}\text { Market } \\
\text { characteristic }\end{array}$ & $\begin{array}{l}\text { Probability of } \\
\text { losing the market } \\
\text { share due to } \\
\text { worsening of } \\
\text { competitive } \\
\text { advantages }\end{array}$ & $\begin{array}{l}\text { Degree of } \\
\text { substitution } \\
\text { with } \\
\text { imports in } \\
\text { the internal } \\
\text { market }\end{array}$ \\
\hline V. & $\begin{array}{l}1,800<\mathrm{HHI}<10 \\
, 000,0<\mathrm{IL}<1\end{array}$ & $\begin{array}{l}\text { Medium } \\
\text { low }\end{array}$ & $\begin{array}{l}\text { Oligopolistic } \\
\text { competition } \\
\text { market }\end{array}$ & $\begin{array}{l}\text { Medium } \\
\text { high }\end{array}$ & $\begin{array}{l}\text { Lack of } \\
\text { manufacturers } \\
\text { The degree of } \\
\text { the region's } \\
\text { specialization } \\
\text { is low }\end{array}$ & High & $\begin{array}{l}\text { Medium } \\
\text { high }\end{array}$ \\
\hline VI. & $\begin{array}{l}1,800<\mathrm{HHI}<10 \\
, 000, \mathrm{IL}>1\end{array}$ & Low & $\begin{array}{l}\text { Pure } \\
\text { monopoly } \\
\text { market/oligop } \\
\text { olistic } \\
\text { competition } \\
\text { market }\end{array}$ & High & $\begin{array}{l}\text { Lack of } \\
\text { manufacturers, } \\
\text { high degree of } \\
\text { the region } \\
\text { specialization }\end{array}$ & Low & Low \\
\hline VII. & $\begin{array}{l}\mathrm{HHI}=10,000, \\
\mathrm{IL}>1\end{array}$ & $\begin{array}{l}\text { No } \\
\text { competiti } \\
\text { on }\end{array}$ & $\begin{array}{l}\text { Pure } \\
\text { monopoly } \\
\text { market }\end{array}$ & Maximum & $\begin{array}{l}\text { Single } \\
\text { manufacturer }\end{array}$ & Ultimately low & $\begin{array}{l}\text { Ultimately } \\
\text { low }\end{array}$ \\
\hline VIII. & $\begin{array}{l}\mathrm{HHI}>1,800, \\
\mathrm{IL}=0\end{array}$ & $\begin{array}{l}\text { Absence } \\
\text { of own } \\
\text { productio } \\
\mathrm{n} \text { in the } \\
\text { region }\end{array}$ & $\begin{array}{l}\text { Pure } \\
\text { monopoly } \\
\text { market }\end{array}$ & - & $\begin{array}{l}\text { The only } \\
\text { manufacturer } \\
\text { in the market }\end{array}$ & - & \\
\hline
\end{tabular}

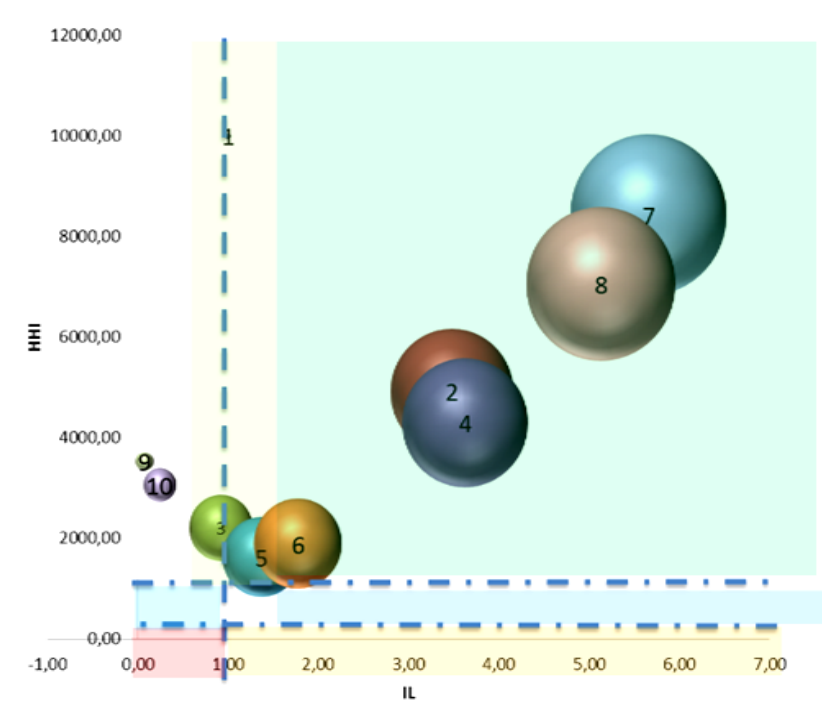

Figure 2. The degree of competition of certain types of economic activities related to the chemical and related to it sectors of industry of the Republic of Tatarstan in the Volga Federal District, as of 2012

1. Manufacture of gas carbon, 2. Manufacture of soap and detergents, 3. Manufacture of petroleum products, 4. Manufacture of plastics and synthetic resin in primary forms, 5. Manufacture of plastic products, 6 . Manufacture of other non-metallic mineral products, 7. Manufacture of rubber tires and tubes, 8. Manufacture of synthetic rubber, 9. Manufacture of fertilizers and nitrogen compounds, 10. Manufacture of pharmaceutical products.

\section{Discussion}

Based on the performed analysis of competitive market profiles of industrial types of economic activity of the 
Republic of Tatarstan, they were categorized based on the probability of their development prospects with account of specific parameters of their market surrounding and trends of the competition development in the respective segments of the industrial manufacture of the Volga Federal District.

I. Types of economic activity of industrial profile of the Republic of Tatarstan described with low degree of competitiveness in the Volga Federal District, with a high probability of losing the market share due to weakening competitive advantages $(\mathrm{HHI}<1,000,0<\mathrm{IL}<1$; low degree of specialization in the highly competitive market), as:

1) Ready groceries; alcohol and alcohol-free beverages and vinegar; tobacco and substitutes:

-manufacture of mineral water;

-manufacture of meat and meat products.

2) Machines, equipment and mechanisms; electric technical equipment; their parts; sound-recording and sound-reproducing devices, devices for recording and reproducing television images and sound, their parts and accessories:

-manufacture of devices and tools for measuring, verifying, testing, navigating, controlling and for other purposes.

II. The types of economic activity of the Republic of Tatarstan carried out in the market of monopolistic competition in the Volga Federal District, which have medium high competitive advantages determined by the considerable degree of localization (specialization) ( $\mathrm{HHI}<1,000$, IL $>1$; High degree of specialization in the highly competitive market).

There are no types of economic activity in the Republic of Tatarstan that would relate to this type of a market. At the same time, the type of economic activity "Manufacture of devices and tools for measuring, verifying, testing, navigating, controlling and for other purposes" is described with high degree of probability of transition from the first group to the second, provided the localization index increases from 0.78 to 1 . Thus, the considered type of economic activity despite unstable competitive positions in the Volga Federal District has good chances to proceed to a higher level of competitiveness in case of relatively insignificant stimulation of volumes of economic activity.

III. The types of economic activity of the Republic of Tatarstan being present in the market of oligopolistic competition described by low degree of localization (specialization) in the Volga Federal District. Manufactures included in this group have relatively low competitive positions and are described with rather high probability of their worsening. At the same time, the types of economic activity included in this group have high potential and need intensification of certain measures targeting increase in the market shares in order to reinforce their competitiveness $(1,000<\mathrm{HHI}<1,800,0<\mathrm{IL}<1$; low degree of localization (specialization) of manufacture in a medium concentrated market), as:

1) Textile materials and textile products:

-manufacture of outwear;

-manufacture of clothes made of textile materials and clothing accessories;

2) Ready groceries; alcohol and alcohol-free beverages and vinegar; tobacco and substitutes:

-manufacture of flour from grain and vegetable crops and ready flour mixtures and dough for baking;

-manufacture of beer;

-manufacture of products from meat and poultry;

-manufacture of flour and grit products;

-manufacture of ready and preserved products from meat, poultry, meat by-products and blood of animals.

3) Machines, equipment and mechanisms; electric technical equipment; their parts; sound-recording and sound-reproducing devices, devices for recording and reproducing television images and sound, their parts and accessories:

-manufacture of railway rolling stock (locomotives, motorized tram wagons and other rolling stock);

-manufacture of electric machines and electric equipment;

-manufacture of electric motors, generators and power converters.

IV. The types of economic activity of the Republic of Tatarstan carried out in the market of oligopolistic 
competition, which have high competitive potential with account of the high degree of manufacture localization. Enterprises operating in this market type are described with stable position in the market and low probability of losing the market share due to weakening competitive advantages. $(1,000<\mathrm{HHI}<1,800$, IL $>1$; high degree of specialization in a highly competitive market), as:

1) Products of chemical and related to it sectors of industry: -manufacture of plastic articles.

2) Ready groceries; alcohol and alcohol-free beverages and vinegar; tobacco and substitutes: -manufacture of dairy products;

-manufacture of dry bread and flour products and flour confectionery goods with extended storage period; -manufacture of whole-milk products;

V. Types of economic activity of the Republic of Tatarstan operating in a highly concentrated market, which predetermines their oligopolistic orientation with elements of monopolistic competition. At the same time, the types of economic activity included in this group are described with poor localization, which determines their vulnerability in the "competition area". The types of manufactures considered by us need reinforcement of competitive positions through increasing their market share. Otherwise, the probability of losing the market share becomes threatening $(1,800<\mathrm{HHI}<10,000,0<\mathrm{IL}<1$; low level of localization (specialization) in a highly concentrated market), as:

1) Products of chemical and related to it sectors of industry:

-manufacture of petrochemicals;

-manufacture of fertilizers and nitrogen compounds;

-manufacture of pharmaceutical products;

2) Textile materials and textile products:

-manufacture of ready textile articles, except for clothes;

-manufacture of leather clothes;

-manufacture of clothes, accessories and other products from fur, except for headwear;

-manufacture of workwear;

-leather tannage and finishing.

3) Ready groceries; alcohol and alcohol-free beverages and vinegar; tobacco and substitutes:

-manufacture of alcohol-free beverages, except for mineral water;

-manufacture of mineral water and other alcohol-free beverages;

-manufacture of milk, cream, and other dairy products in solid states.

4) Machines, equipment and mechanisms; electric technical equipment; their parts; sound-recording and sound-reproducing devices, devices for recording and reproducing television images and sound, their parts and accessories:

-manufacture of passenger vehicles;

-manufacture of vehicle bodies; manufacture of trailers, semi-trailers and containers designed for transportation by one or several types of transport;

-manufacture of home non-electric appliances;

-manufacture of home electric appliances;

-manufacture of machines used in crop husbandry;

-manufacture of equipment, which has not been included in other groups, dedicated for processing substances using processes that involve environment temperature change.

-manufacture of office equipment and computers;

-manufacture of industrial refrigerating and ventilating machinery;

-manufacture of parts and accessories of vehicles and their engines;

-manufacture of electrical and radioelements, electrical vacuum devices, television and radio transmission 
equipment, and electrical communication equipment;

-manufacture of electronic components, equipment for radio, television, and communication.

VI. Types of economic activity of the Republic of Tatarstan, the competitiveness of which is on a high level. Manufactures that create this group have high degree of localization in the market with a very limited number of participants. This format predetermines the prevailing form of economic activity in the district. $(1,800<\mathrm{HHI}<10,000, \mathrm{IL}>1$; high degree of localization (specialization) in a highly competitive market), as:

1) Mineral products:

-crude oil extraction.

2) Products of chemical and related to it sectors of industry:

-manufacture of soap and cleaning agents;

-manufacture of plastics and synthetic resins in primary forms;

-manufacture of other non-metallic mineral products;

-manufacture of rubber tires, treads, and inner tubes;

-manufacture of synthetic rubber.

3) Textile materials and textile products:

-manufacture of footwear;

-manufacture of knitwear.

4) Ready groceries; alcohol and alcohol-free beverages and vinegar; tobacco and substitutes:

-manufacture of butter;

-manufacture of grains, coarse flour, granules and other products from grain crops;

-manufacture of ice cream;

-manufacture of meat;

-manufacture of meat and edible by-products of poultry and rabbits;

-manufacture of poultry and rabbit meat;

-manufacture of vegetable and animal oils and fats, except for margarine products;

-manufacture of cheese;

-manufacture of sugar;

5) Machines, equipment and mechanisms; electric technical equipment; their parts; sound-recording and sound-reproducing devices, devices for recording and reproducing television images and sound, their parts and accessories:

-manufacture of tractors for agriculture;

-manufacture of commercial vehicles;

-manufacture of air and vacuum pumps; manufacture of air and gas compressors;

-manufacture of internal combustion engines for vehicles;

-manufacture of engines and turbines, except for aircraft, vehicle, and motorcycle engines;

-manufacture of flying machines;

-manufacture of machines and equipment for agriculture and forestry;

-manufacture of optical devices, photo and cine equipment;

-manufacture of technological process control and regulation devices;

-manufacture of clocks and other horological instruments.

VII. Type of economic activity of the Republic of Tatarstan operating in the purely monopolistic market. Manufactures creating this group have ultimate competitiveness due to absence of other market players ( $\mathrm{HHI}=10,000, \mathrm{IL}>1)$, as:

1) Textile materials and textile products: 
-manufacture of clothes from felt, non-fabric materials, textile materials with steeping or coating.

2) Ready groceries; alcohol and alcohol-free beverages and vinegar; tobacco and substitutes:

-manufacture of starch and starch products; manufacture of sugars and sugar syrups, which are not included in other groups;

-manufacture of malt;

VIII. Types of economic activity not represented in the market of the Republic of Tatarstan. Entrance in the market is hindered by the high degree of concentration of manufacture in the Volga Federal District, which determines the scale effect and, accordingly, forms competitive barriers in the form of resource restrictions. $(\mathrm{HHI}>1,800, \mathrm{IL}=0)$, as:

1) Mineral products:

-manufacture of charred coal;

2) Textile materials and textile products:

-manufacture of underwear;

-manufacture of jersey fabric.

-manufacture of curtain lace, lacework, narrow fabrics, needlework;

-manufacture of cotton fabric;

-manufacture of silk fabric;

-manufacture of woolen fabric of fiber of carded filature.

3) Ready groceries; alcohol and alcohol-free beverages and vinegar; tobacco and substitutes:

-processing and preservation of vegetables;

-processing and preservation of fruits and nuts;

-manufacture of grape wines;

-manufacture of cocoa, chocolate and sugary confectionary products;

-manufacture of macaroni products;

-manufacture of margarine;

-manufacture of margarine products;

-manufacture of meat and food by-products of cattle, swine, sheep, goats, horses;

-manufacture of vegetable refined oils and fats;

-manufacture of vegetable juices and extracts, peptic substances, vegetable clues and thickeners;

-manufacture of refined oils and fats;

-manufacture of condensed dairy products and dairy products not included in other groups;

-manufacture of curd and creamed curd products;

-manufacture of tobacco products.

4) Machines, equipment and mechanisms; electric technical equipment; their parts; sound-recording and sound-reproducing devices, devices for recording and reproducing television images and sound, their parts and accessories:

-manufacture of buses and trolleybuses;

-manufacture of motorcycles and bicycles;

-manufacture of equipment for receipt, recording and reproducing sound and image;

-manufacture of fans;

-manufacture of hydraulic and pneumatic power units and engines;

-manufacture of wood-processing equipment;

-manufacture of sound-recording and sound-reproducing equipment and equipment for recording and reproducing images; 
-manufacture of cranes, except for construction cranes;

-manufacture of machines for cattle breeding;

-manufacture of machines and equipment for extraction of minerals and construction;

-manufacture of machines and equipment for production of paper and cardboard;

-manufacture of machines and equipment for production of groceries, including beverages, and tobacco products;

-manufacture of machines and equipment for production of textile, sewn, fur, and leather products;

-manufacture of machines and equipment for metallurgy;

-manufacture of metal-cutting machine-tools;

-manufacture of equipment for soldering, welding and cutting, machines and devices for surface heat treatment and hot spraying;

-manufacture of equipment for preparation of textile fibers, filature, contexture, and knitting of textile products;

-manufacture of stream-flow transport equipment;

-manufacture of parts of railway locomotives, tram and other motorized wagons and rolling stock; manufacture of railway equipment and devices for railways, street railway, and other ways;

-manufacture of electronic computing devices and other equipment for information processing;

-manufacture of electrical equipment for engines and vehicles.

\section{Summary}

Based on the performed analysis of the competitiveness of the industrial profile of the Republic of Tatarstan in the Volga Federal District, we can form basic recommendations targeting formation of a system of measures of government control of development of industrial markets in the Republic of Tatarstan. Among the total of industrial types of economic activity represented by the Republic of Tatarstan in the Volga Federal District, such types of economic activity as manufacture of mineral water, manufacture of meat and meat products, manufacture of devices and tools for measuring, verifying, testing, navigating, controlling and for other purposes are in the least stable position in terms of current indicators of competitiveness.

Beside the specified types of economic activity in the structure of the industrial profile of the Republic of Tatarstan, there are manufactures, which have vulnerable positions in the "competition area" of the Volga Federal District (with account of different ratio of the market concentration and manufacture localization indexes). In this view, it is necessary to encourage reinforcement and increase of the potential of the types of economic activity under consideration by way of adoption of special dedicated measures based on increasing costs for implementation of active programs of supporting manufactures, which have low or insignificant (moderate) degree of competitiveness.

\section{Credits}

The work was carried out at the expense of the grant assigned to the Kazan Federal University for fulfillment of the government order in the sphere of scientific activity.

\section{References}

Abdullina, S. N. (2000). The Philosophy of Integration Processes in Economics, Science and Practice. In S. N. Abdullina (Ed.), The Socio-Economic Problems of Formation and Development of Market Economy (pp. 155-157). Kazan.

Age shall weary them. The productivity challenge of the rich world's demography. (2013, May 17). The Economist, 11. Retrieved June 3, 2014, from http://www.economist.com/news/finance-and-economics/ 21577414-productivity-challenge-rich-worlds-demography-age-shall-weary-them

Ageev, A., Kuroedov, B., \& Sandarov, S. (2008). The Strategic Matrix and the Rating of Regions of Russia. Ekonomicheskiye Strategii, 7(65), 116-121.

Brown, D. J., \& Earle, J. S. (2008). Employment Reallocation and Productivity Growth in Transition: An International; Comparative Analysis (p. 41). UK, Edinburgh: Upjohn University for Employment Research.

Davletshin, I. A. (2011). Modelling Efficient Risk Management at Enterprises of the Petrochemical Cluster of the Region. Makroekonomika, 2, 107-111. 
Fursenko, A. A. (2003). Government Innovative Policy: The Priorities and the Prospects. In the Proceedings of the Forum "The North-West of Russia: The Window to the Global World", the Round Table "the Innovative Strategy of Russia: A Glance into the Future", Saint Petersburg. Retrieved February 15, 2014, from http://www.csr-nw.ru/public_docs/031114_doklad_Fursenko.doc

Gafurov, I. R., Safiullin, M. R., \& Safiullin, A. R. (2012). The Analysis of Structural Gaps between the Competitiveness of Manufactures of the Petrochemical Cluster of the Republic of Tatarstan (p. 286). Kazan: the Kazan University.

Galeeva, G. M. (2012). Innovations as an Element of Strategic Management and Improvement of Competitiveness of Enterprises of the Petrochemical Cluster of the Republic of Tatarstan. Natsionalnye Interesy: Prioritety i Bezopasnost, 36, 46-51.

Granberg, A. G., \& Mikheeva, N. N. (2009). The Effect of the Global Crisis on the Strategy of Spatial Socio-economic Development of the Russian Federation. Region: Ekonomika i Sotsiologia, 4, 69-101.

Krasnova, O. M., \& Galdina, A. A. (2012). Assessment of the Non-Observed Economy of the Republic of Tatarstan. Ekonomichesky Vestnik Respubliki Tatarstan, 4, 25.

Order of the Government of the Russian Federation "the Concept of Long-Term Socio-Economic Development of the Russian Federation until 2020" of 17.11.2008 \# 1662-r.

Porter, M. (2000). Competition (p. 8). Saint Petersburg: the Williams Publishing House.

Safiullin, A. R. (2011). Competitive advantages (the territory and sector-related level) (p. 302). Germany: LAPLAMBERT Academic Publishing GmbH\&Co. KG.

Safiullin, M. R., Elshin, L. A., \& Shakirova, A. I. (2013). Positioning of Regions Based on Aggregate Index of Socio-economic Attractiveness and Detection of Strategic References for Further Growth. Ekonomichesky Vestnik Respubliki Tatarstan, 2, 7.

Safiullin, M. R., Elshin, L. A., \& Shakirova, A. L. (2012). Assessment of the Business and Economic Activity as a Tool of Short-Term Forecasting. Vestnik Rossiyskoy Akademii Nauk, 7, 623.

Safiullin, M. R., Elshin, L. A., Prygunova, M. I., \& Galyavov, A. A. (2013). Complex Analysis of Prospects of the Volga Federal District Regions Development: Methodology and Practice. World Applied Sciences Journal, 27(4), 508-511.

Shirov, A. A., Gusev, M. S., Yantovsky, A. A., \& Potapenko, V. V. (2012). Long-term Development of the Russian Economy and the Problem of Efficiency of Utilization of Labor Resources. Problemy Prognozirovaniya, $1,9$.

The concept of the Strategy of Socio-Economic Development of Regions of the Russian Federation. the Ministry of Regional Development of the Russian Federation. Retrieved February 10, 2014, from http://www.minregion.ru/activities/territorial_planning

The Decree of the Government of the Republic of Tatarstan "On approval of the Program of Development and Localization of Productive Forces of the Republic of Tatarstan based on Cluster Approach until 2020 and for the Period until 2030" of 22.10.2008 \# 763.

The Program of Socio-Economic Development of the Republic of Tatarstan in 2011-2015. Retrieved February 18, 2014, from http://www.mep.tatar.ru

Tokarev, A. N. (2013). The innovative development of the oil and gas sector of Russia: The strategy and the tactics, the prerequisites and the effects. Retrieved September 30, 2013, from http://law.admtyumen.ru/noframe/nic?d\&nd=466201944

\section{Copyrights}

Copyright for this article is retained by the author(s), with first publication rights granted to the journal.

This is an open-access article distributed under the terms and conditions of the Creative Commons Attribution license (http://creativecommons.org/licenses/by/3.0/). 